\title{
Atypical presentation of opioid withdrawal, an effect of adulteration
}

\author{
Supriya Kumar Mondal ${ }^{*}$, Biswadeep Borthakur ${ }^{2}$, Kamala Deka ${ }^{3}$, Sabita Dihingia ${ }^{4}$, Dhruba Jyoti Bhuyan ${ }^{4}$ \\ From First International Science Symposium on HIV and Infectious Diseases (HIV SCIENCE 2012) \\ Chennai, India. 20-22 January 2012
}

\section{Background}

Brown sugar is the impure form of di-Acetyle Morphine with comparable pharmacological effect and withdrawal symptoms. Recent observation regarding the atypicality withdrawal symptomatology in opioid dependants stimulated the present study.

\section{Purpose}

To study the abuse pattern and symptom profile in withdrawal state of brown sugar abusers.

\section{Methodology}

Consecutive sampling method was used to collect patients with opioid dependence according to DSM IV TR. Abuse pattern was assessed through semi-structure proforma, withdrawal symptoms through clinical opioid withdrawal scale and also chemical analysis of the drug.

\section{Results}

Among patients $43.396 \%$ had seizure, 26.086\% developed confusion after seizure and $17.391 \%$ experienced psychotic symptoms. Longer duration and larger quantity of substance abuse leads to higher complications. Seizure episodes occurred between 11 to $92 \mathrm{hrs}$ of last intake with a median of $30 \mathrm{hrs}$. The seizure frequency had strong correlation with daily doses $(\beta-0.697)$ and frequency $(\mathrm{r}-0.527)$ but is weakly correlated with withdrawal severity $(r-0.425)$. Chemical analysis of illicit drug revealed that caffeine constitutes greater proportion and opioid like substance a minor quantity.

\section{Conclusion}

Complications like seizure, delirium and psychosis are common in withdrawal. Complication is higher among

\footnotetext{
* Correspondence: drsupriyakumarm@gmail.com

${ }^{1}$ Central Institute of Psychiatry, Ranchi, Jharkhand, India

Full list of author information is available at the end of the article
}

high quantity and high frequency users. Delirium and psychosis might be a complication of seizure. Adulteration with toxic substance might be a cause for atypical symptoms which leads to a life threatening condition and warrants preventive cure from such illicit drug as opium substitution therapy.

\section{Author details}

${ }^{1}$ Central Institute of Psychiatry, Ranchi, Jharkhand, India. ${ }^{2}$ A.R.T Centre, Assam Medical College, Dibrugarh, Assam, India. ${ }^{3}$ Jorhat Medical College, Jorhat, Assam, India. ${ }^{4} \mathrm{AMCH}$, Dibrugarh, Assam, India.

Published: 4 May 2012

\section{doi:10.1186/1471-2334-12-S1-P76}

Cite this article as: Mondal et al: Atypical presentation of opioid withdrawal, an effect of adulteration. BMC Infectious Diseases 201212 (Suppl 1):P76.
Submit your next manuscript to BioMed Central and take full advantage of:

- Convenient online submission

- Thorough peer review

- No space constraints or color figure charges

- Immediate publication on acceptance

- Inclusion in PubMed, CAS, Scopus and Google Scholar

- Research which is freely available for redistribution

Submit your manuscript at www.biomedcentral.com/submit
C Biomed Central 